\title{
Implementing Differentiated Instruction into the Physical Education Classroom 應用區别化教學於體育課
}

\author{
Amanda Kaldor \\ Bennett Elementary \\ Fargo, ND \\ U.S.A.
}

Joe DEUTSCH

Department of Physical Education

North Dakota State University

Fargo, ND

U.S.A.

\section{Introduction}

Throw out the ball and blow the whistle, it's easy to do. Use curriculum by following it step by step and not differ from a single lesson. These are common practices done by physical education teachers every day. It's easy to continue to teach in the same way, with the same assessments, and not consider where students are at in their learning or how they learn best. In today's classroom or gymnasium it is very difficult for students to reach their full potential while teaching in this traditional manner. Haager and Klinger (2005) suggest that "a major drawback of traditional instruction is that many teachers teach to the middle, which means the needs of a growing number of students will go unmet" (p. 19). One potential solution to this problem is differentiated instruction.

Differentiated instruction (DI) is the process of "ensuring that what a student learns, how he/she learns it, and how the student demonstrates what he/she has learned is a match for that student's readiness level, interests, and preferred mode of learning" (Tomlinson, 2004, p.188).
The process of differentiation in physical education can seem daunting especially since little is written about specifically differentiating in the physical education classroom. With just a little creativity, some research, and a few resources DI can be implemented and the physical education curriculum can be adapted.

\section{Where to Start}

Sarason (1971) states that teachers do not begin teaching students at the level they are at, but at a predetermined point in their curriculum. Instead of starting where curriculum the indicates, try a preassessment. Pre-assessments can be very simple and do not have to take a lot of time. Since we want to keep our students active the majority of time, informal pre-assessments are a good choice for physical education teachers. Table 1 shows some simple pre-assessments and how to use them in the physical education classroom. 
Table 1. Pre-Assessment to Modifications.

\begin{tabular}{|c|c|c|c|}
\hline $\begin{array}{c}\text { Informal pre-assessment } \\
\text { strategy }\end{array}$ & $\begin{array}{l}\text { How to use it in the } \\
\text { classroom }\end{array}$ & $\begin{array}{c}\text { Modifications for Physical } \\
\text { Education }\end{array}$ & Remember... \\
\hline Topic Webs & $\begin{array}{l}\text { Students use sticky notes to } \\
\text { write facts they already know } \\
\text { about the topic. Notes are } \\
\text { shared with others in small } \\
\text { groups and are then assigned } \\
\text { to categories in the topic web. }\end{array}$ & $\begin{array}{l}\text { Play a tag game. When a } \\
\text { student gets tagged he or she } \\
\text { must come to you and tell you } \\
\text { one fact about the topic. Or } \\
\text { have students freeze when } \\
\text { tagged. In order to get unfrozen } \\
\text { they must tell another student } \\
\text { a fact about the topic. Walk } \\
\text { around and listen to their } \\
\text { answers. }\end{array}$ & $\begin{array}{l}\text { Since we are just using } \\
\text { this as a pre-assessment } \\
\text { we don't necessarily } \\
\text { have to make the topic } \\
\text { web. But this does let } \\
\text { you know what each } \\
\text { student already knows } \\
\text { or doesn't know about } \\
\text { the topic. }\end{array}$ \\
\hline $\begin{array}{l}\text { Walkabout charts } \\
\text { What happens to our bodies } \\
\text { when we exercise? } \\
\text { Why does our body sweat? } \\
\text { What happens to our heart rate } \\
\text { when we exercise? } \\
\text { What happens to our face } \\
\text { when we exercise? } \\
\text { What happens to our breathing } \\
\text { when we exercise? } \\
\text { Why is exercise important? }\end{array}$ & $\begin{array}{l}\text { Place } 4 \text { to } 6 \text { questions on a } \\
\text { chart related to your unit. } \\
\text { Have students walk around } \\
\text { and find other students who } \\
\text { know the answer to one } \\
\text { of the questions. Lead the } \\
\text { class in discussion and then } \\
\text { collect the charts to check } \\
\text { for student understanding or } \\
\text { misunderstanding. }\end{array}$ & $\begin{array}{l}\text { This one can be used very } \\
\text { similar to the classroom use. } \\
\text { Try switching locomotor skills } \\
\text { when students are moving } \\
\text { around the gym. }\end{array}$ & $\begin{array}{l}\text { Always move around } \\
\text { the gym and listen to the } \\
\text { students give answers } \\
\text { and ask questions. This } \\
\text { can be a pre-assessment } \\
\text { strategy itself. }\end{array}$ \\
\hline $\begin{array}{l}\text { Knowledge Bar Graphs } \\
\text { I have no clue about } \\
\text { flexibility } \\
\text { I know a little about flexibility } \\
\text { and can show you one stretch } \\
\text { I am an expert and can show } \\
\text { you } 4 \text { or more stretches }\end{array}$ & $\begin{array}{l}\text { Create a bar graph on the } \\
\text { board. After a brief overview } \\
\text { of the unit show the students } \\
\text { the bar chart. Hand out sticky } \\
\text { notes and have each child } \\
\text { write their name on the back. } \\
\text { Have them place their sticky } \\
\text { note on the section of the } \\
\text { chart that best represents their } \\
\text { knowledge. }\end{array}$ & $\begin{array}{l}\text { Can be used as is with a few } \\
\text { small changes. To save class } \\
\text { time, prewrite each child's } \\
\text { name on the back of the sticky } \\
\text { note. Play a game and have the } \\
\text { students put their sticky note on } \\
\text { the chart at some point during } \\
\text { the game. This will prevent } \\
\text { overcrowding and keep kids } \\
\text { active. }\end{array}$ & $\begin{array}{l}\text { Collect the sticky notes } \\
\text { from the graph at the } \\
\text { end of class making } \\
\text { sure to keep them in } \\
\text { order according to } \\
\text { categories. This will } \\
\text { allow you to see which } \\
\text { students need more } \\
\text { help and which students } \\
\text { already understand. }\end{array}$ \\
\hline Check in Slips & $\begin{array}{l}\text { Students answer two or } \\
\text { three quick questions at the } \\
\text { beginning of class to assess } \\
\text { their background knowledge } \\
\text { on a subject. }\end{array}$ & $\begin{array}{l}\text { Use as a cool-down. Ask one } \\
\text { question and have students write } \\
\text { their answer on an index card. } \\
\text { Collect the index cards as the } \\
\text { students leave the gym. }\end{array}$ & $\begin{array}{l}\text { For younger students } \\
\text { ask them to draw a } \\
\text { picture or talk in a large } \\
\text { group. }\end{array}$ \\
\hline
\end{tabular}




\section{Modifying Curriculum and Implementing Differentiated Instruction}

The next step is to begin modifying unit goals and developing an instructional plan using assessments and differentiated instruction. Using the information gained from pre-assessment adaptations can be made to lesson plans. Omitting some lessons may be a possibility if students already know the material, or extra time may be spent on concepts students don't understand.
Formative assessment may also be used to monitor students' progress. This allows you to identify which students have reached learning goals and which students need more time or practice. Formative assessments may be informal (e.g. observation or feedback) or formal. Just like pre-assessment, these are not graded and are simply used to assess student learning. There are many formative assessments already designed for classroom use. Instead of reinventing the wheel, adapt them, or use ones that will work in the physical education classroom. Table 2 shows a few ideas for formative assessments.

Table 2. Formative Assessments.

\begin{tabular}{|l|l|l|l|}
\hline \multicolumn{1}{|c|}{ Formative assessments } & How to use it in the classroom & $\begin{array}{l}\text { Modifications for Physical } \\
\text { Education }\end{array}$ & \multicolumn{1}{|c|}{\begin{tabular}{l} 
Remember... \\
\hline A \& D (Agree/Disagree) Statements
\end{tabular}} \\
\hline $\begin{array}{l}\text { Students analyze a set of fact } \\
\text { or fiction statements about the } \\
\text { facts or concepts you have } \\
\text { been teaching. }\end{array}$ & $\begin{array}{l}\text { Read a question out loud } \\
\text { to your students if they } \\
\text { agree they do 5 jumping } \\
\text { jacks if they disagree they } \\
\text { do 5 mountain climbers. }\end{array}$ & $\begin{array}{l}\text { Another option... } \\
\text { Have students stand } \\
\text { on a center line. } \\
\text { Label one wall agree } \\
\text { and one disagree. } \\
\text { They must run to the } \\
\text { wall that corresponds } \\
\text { with their answer. }\end{array}$ \\
\hline Fist to Five & $\begin{array}{l}\text { Students indicate knowing } \\
\text { by using their fist (nothing } \\
\text { known) to 5 fingers to indicate } \\
\text { their extent of understanding of } \\
\text { a concept or procedure }\end{array}$ & $\begin{array}{l}\text { Works great as is for PE. } \\
\text { A quick and easy way to } \\
\text { check for understanding. }\end{array}$ & $\begin{array}{l}\text { A question may be } \\
\text { asked while students } \\
\text { are frozen. Several } \\
\text { questions don't have } \\
\text { to be asked at once. }\end{array}$ \\
\hline No Hands Questioning & $\begin{array}{l}\text { Teacher asks questions about } \\
\text { learning and no one raises their } \\
\text { hands, they are just called on at } \\
\text { random. }\end{array}$ & $\begin{array}{l}\text { Another great quick } \\
\text { formative assessment } \\
\text { strategy for PE. }\end{array}$ & $\begin{array}{l}\text { Again, ask one } \\
\text { question at a time } \\
\text { so students are not } \\
\text { sitting for long } \\
\text { periods of time. }\end{array}$ \\
\hline
\end{tabular}

\section{Differentiating Your Lessons}

After formative assessments have taken place, look at the unit plan and adjust teaching to fit student learning. If there is a wide variety of student understanding, use DI strategies to help each student reach their full potential. Here are a couple of DI strategies that work great in the physical education classroom.

\section{Differentiating by Choice}

Giving the students a choice is one of the best ways to motivate students to learn. It is often one of the first and easiest methods teachers try in differentiation. Choice provides students with a way to act on their interests and hooks them into their learning (Heacox, 2009). 
Choice can be offered in three different areas; content, process, or product. If giving students choice in content, students select what they might learn. In physical education, this may involve allowing students to pick from a list of sports and learn the motor skills associated with that sport. Rubrics can be given to assist the students. If giving the students a choice in the process, the students then choose how they learn. This may involve students choosing to work on a skill with a partner or on their own. It may also be that some students learn about striking by hitting a ball in baseball and others learn about striking by playing tennis. Think about Blooms taxonomy when looking at ways to differentiate by process. If giving students choice in product, students choose how they will demonstrate what they have learned. Think about Gardner's Multiple Intelligences when looking at ways to differentiate by product (Heacox, 2009).

\section{Tic-Tac-Toe Boards}

A great way to differentiate by choice is through the use of tic-tac-toe boards. This would work great as a warm up or fitness activity in the physical education classroom. Tic-tac-toe boards give students nine choices requiring them to complete three in a row. Heacox (2009) gives a few suggestions when making tic-tac-toe boards:

- Make sure the activities on the board are helping students to reach their learning goals.

- Create tasks for different readiness levels, or levels of complexity.

- Arrange activities to control students' choices.

- Arrange tic-tac-toe boards so every student must complete at least one advanced activity.

Table 3 shows an example of a tic-tac-toe board for upper body strength in preparation for fitness testing. Notice tasks are labeled with $\mathrm{A}$ for advanced and B for beginner. When using the tic-tac-toe boards with students make sure to omit the $\mathrm{A}$ and $\mathrm{B}$ from each square. This is simply a way to make sure the tic-tac-toe board is laid out correctly. Also notice the center square has the word all written in it. This is another way to control student choice. This means all students need to go through the middle to achieve their three in a row.

Table 3. Tic-Tac-Toe Board for Upper Body Strength.

\begin{tabular}{|c|c|c|}
\hline $\begin{array}{l}\text { 10 Triceps Dip } \\
\text { - In a crab walk position put } \\
\text { your hands on the bench } \\
\text { Bend arms and lower your } \\
\text { body down but do not let } \\
\text { your bottom touch the floor } \\
\text { Push with your arms back to } \\
\text { a crab walk position }\end{array}$ & \begin{tabular}{l}
\multicolumn{1}{c}{ Tripod } \\
- $\quad$ Get in push-up position \\
- $\quad$ Raise one arm and set it on \\
your back \\
- Hold the balance for 15 \\
seconds \\
Switch arms
\end{tabular} & $\begin{array}{l}\text { 5 Spade Push-ups } \\
\text { - Get in push-up position } \\
\text { - Make a diamond shape with } \\
\text { your thumbs and pointer } \\
\text { fingers } \\
\text { - Using that hand position do } \\
5 \text { spade push-ups }\end{array}$ \\
\hline $\begin{array}{l}\text { 10 Inchworms } \\
\text { - Start in push up position } \\
\text { - Walk feet up to hands without } \\
\text { moving your hands } \\
\text { Walk your hands out back to } \\
\text { a push up position }\end{array}$ & \begin{tabular}{ll}
\multicolumn{1}{c}{7 push-ups } \\
- $\quad$ Keep your body straight \\
- $\quad$ Bend arms to 90 degree angle \\
- \\
Do not let any part of your \\
body touch the floor
\end{tabular} & $\begin{array}{l}\text { 20 Belly Angels } \\
\text { - Lie down on stomach with } \\
\text { your arms at your side } \\
\text { Move arms from sides to } \\
\text { above your head without } \\
\text { your arms touching the } \\
\text { ground }\end{array}$ \\
\hline $\begin{array}{l}\text { 20 Body Bar Presses } \\
\text { - } \quad \text { Lay on your back } \\
\text { - Start with arms straight } \\
\text { and slowly lower bar to } \\
\text { your chest without actually } \\
\text { touching your chest } \\
\text { Slowly push the bar back to } \\
\text { starting position }\end{array}$ & $\begin{array}{l}\text { 15 Wall push-ups } \\
\text { Stand against a wall with } \\
\text { your body straight and your } \\
\text { arms straight } \\
\text { Lean into the wall by bending } \\
\text { your elbows so your nose } \\
\text { almost touches the wall } \\
\text { Push with your arms back to } \\
\text { your beginning position }\end{array}$ & $\begin{array}{l}10 \text { Medicine ball throws } \\
\text { - Chest pass the medicine ball } \\
\text { against the wall }\end{array}$ \\
\hline
\end{tabular}


Remember if there are not nine activities to choose from, a two-by-two or four-by-four board may be created. With these boards, decide how many activities students are to complete (Heacox, 2009).

\section{Differentiating using Tiered Assignments}

Another great way to differentiate a lesson is to use tiered assignments. Tiered assignments are designed to specifically address the needs of students. The activity planned may be great for some students, but after using pre-assessments and/or formative assessments there may be a need for more advanced or more simplified activities. This is where tiering works great. Keep in mind these suggestions from Heacox (2009) when creating a tiered assignment:
- Be careful to address the issues of work, fun, and homework. If students look across the gym and see other students doing something they perceive as being more enjoyable or something that requires less work, the design of the tiers may need to be changed.

- Remember tiered assignments are not a summative assessment. They are meant for student to continue to practice working towards their learning goals.

- Only use tiered assessments when there is significant student learning differences. It is not meant to be used as "busy work" for students.

- "There is not one correct way to differentiate a tiered assignment; there are multiple ways, each directed at the particular and specific learning differences that are present" (Heacox, 2009, p. 97).

Table 4 shows an example of a tiered assignment for first graders working on the skill of hopping.

Table 4. Tiered Assignment for Hopping.

\section{KUD-Power learning Target 1.1.1}

MOVEMENT SKULLS: Demonstrates galloping and hopping as basic locomotor skills (i.e., forward movement, step together step, hop on right foot hop on left foot).

Proficient Students will:

1. Take off and land on the same foot with balance

2. Hop in self space for 10 seconds without losing balance or using extraneous arm motion

\begin{tabular}{|lcc|}
\hline Tier 1: For some & Tier 2: For most & Tier 3: For some \\
\hline Hopping without a hula-hoop & Hopping with a hula-hoop & Hopping with a polyspot \\
- Holding on to object & - Take off and land on & Take off and land on \\
(e.g. wall or partner) & same foot & same foot \\
Take off and land on & Hop continuously for & No extra arm movement \\
same foot & 10 sec & is used \\
- Hop continuously for & No extra arm & Hop on right and left \\
as long as possible & movement is used & foot \\
\hline Reprinted with permission from Fargo Public Schools Assessments and Rubrics, Fargo ND, USA.
\end{tabular}




\section{Wrap it Up}

After all of this differentiation, the last step in the teaching/learning process is the summative assessment. By using differentiation, a score increase on student summative assessment should occur. Also, because of planning for expected differences, more students should succeed with the learning goal. Remember the whole point of differentiation is to help each and every student achieve specific learning goals.

Differentiation may be a challenge but the results are worth it. The process does not have to happen all at one time; nor does it have to happen within every unit. Start by trying just one of the DI methods. Look for activities within curriculum that lend themselves to differentiation and remember that the process does not have to be difficult or time consuming. Diane Heacox author of the book Making Differentiation a Habit (2009) gives the best advice when approaching differentiated instruction, "Start small, but start somewhere!".

\section{References}

Fargo Public Schools (2010). Physical Education: Assessments and Rubrics, Fargo, ND.

Haager, D., \& Klinger, J.K., (2005). Differentiating Instruction in Inclusive Classrooms. Columbus, $\mathrm{OH}$ : Merrill.

Heacox, D., (2009). Making Differentiation a habit. Minneapolis, MN: Free Spirit Publishing Incorporated.

Keeley, P. D., (2008). Science Formative Assessment. Thousand Oaks, CA: Corwin Press.

Sarason, S. B., (1971). The Culture of the School and the Problem of Change. Boston, MA: Allyn and Bacon.

Tomlinson C.A., (2004) Sharing responsibility for differentiating instruction. Roper Review, 26, 188-192.

Tomlinson C.A., (2000). Reconcilable differences: Standardsbased teaching and differentiation. Educational Leadership, 58, 6-11.

\section{Correspondence}

Joe Deutsch, Ph.D.

Assistant Professor

Physical Education Pedagogy

North Dakota State University

Fargo, ND

Joe.Deutsch@ndsu.edu

PO Box 6050 Dept. 2620

Fargo, ND 58108, USA

(o) $701-231-5687$

(f) $701-231-8872$

Amanda Kaldor

Physical Education Teacher

Bennett Elementary

Fargo, ND

kaldora@fargo.k12.nd.us

2000 58th Ave. S

Fargo, ND 58104, USA

701-446-4000 